\title{
Making an anti-amastigote vaccine for visceral leishmaniasis: rational, update and perspectives
}

Ana Paula Fernandes ${ }^{1}$, Eduardo Antonio Ferraz Coelho ${ }^{2}$, George Luiz Lins Machado-Coelho ${ }^{3}$, Gabriel Grimaldi Junior ${ }^{4}$ and Ricardo Tostes Gazzinelli ${ }^{5,6,7}$

\begin{abstract}
Visceral leishmaniasis is a major health problem in Latina America, as well as the Mediterranean region of Europe and Asia. We aimed to develop a vaccine against visceral leishmaniasis targeting the intracellular amastigotes, which is the parasite stage that persists throughout infections with Leishmania parasites. With this in mind, we identified an amastigote specific antigen (A2) that contains an immunogenic epitope for CD4+ Thelper (Th) cells and multiple repetitive units encoding CD8+ cytotoxic T lymphocyte (CTL) epitopes.

Vaccine formulations containing the recombinant $A 2$ associated with saponin, alum and IL-12 or expressed by attenuated adenovirus were shown to be protective in mice, dogs and nonhuman-primates. We are currently identifying novel amastigote specific immunogenic proteins that could be aggregated to A2 to further improve the level of vaccineinduced cell-mediated immunity and protection against visceral leishmaniasis.
\end{abstract}

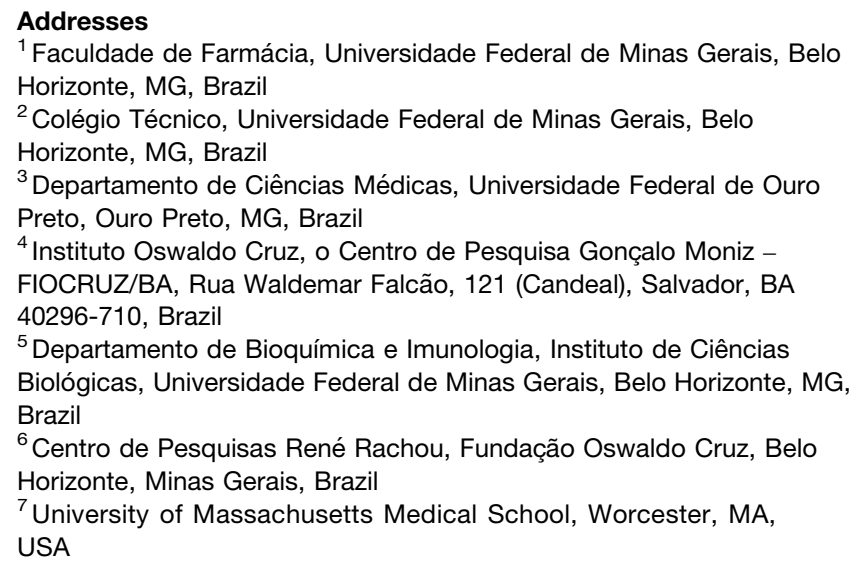

${ }^{5}$ Departamento de Bioquímica e Imunologia, Instituto de Ciências Biológicas, Universidade Federal de Minas Gerais, Belo Horizonte, MG, Brazil

${ }^{6}$ Centro de Pesquisas René Rachou, Fundação Oswaldo Cruz, Belo Horizonte, Minas Gerais, Brazil

${ }^{7}$ University of Massachusetts Medical School, Worcester, MA, USA

Corresponding author: Fernandes, Ana Paula (anapaula.fernandes@pq.cnpq.br, anav@uai.com.br, apfernandes.ufmg@gmail.com)

Current Opinion in Microbiology 2012, 15:476-485

This review comes from a themed issue on Host-microbe interactions: Parasites

Edited by Hugo D Lujan

For a complete overview see the Issue and the Editorial

Available online 13th June 2012

1369-5274/\$ - see front matter, (C) 2012 Elsevier Ltd. All rights reserved.

http://dx.doi.org/10.1016/j.mib.2012.05.002

\section{Introduction}

Leishmaniasis may be best defined as a diverse group of syndromes [ $\left.1^{\bullet}\right]$, caused by several Leishmania species [2]. Visceral leishmaniasis (VL), also known as kala-azar, is the most severe and fatal syndrome, if diagnosis and treatment is not promptly established [3]. Leishmania donovani, L. infantum, L. chagasi (synonymous L. infantum) and $L$. amazonensis are the major species responsible for VL $[4,5]$. These species' parasites are able to migrate to visceral organs causing symptoms such as fever, weight loss, splenomegaly, hepatomegaly and anaemia [3].

Leishmaniasis still threatens 350 million worldwide, being one of the most neglected tropical diseases due to the lack of efficient tools and clear criteria for control [6]. Zoonotic VL is an emerging disease in countries around the Mediterranean basin, in the Middle East, and in Latin America [7]. In these areas, besides sylvatic reservoirs, domestic dogs are the principal urban reservoir of L. infantum and a significant source of infection for vectors. Currently, only few drugs are available for chemotherapy, presenting high toxicity, variable efficacy, inconvenient treatment schedules and costs. Combined therapies are advocated based on the emergence of drug resistant parasites but these remain costly for the majority of patients [8].

In this context, vaccines for human and canine populations are strongly desirable. Here, we discuss the rational for designing an anti-amastigote against VL, highlighting each of the critical steps: (i) antigen selection; (ii) choice of immunologic adjuvants and live attenuated vectors; (iii) testing in different animal models; (iv) development into a commercial vaccine for canine visceral leishmaniasis; and (v) the efforts to improve the current vaccine towards broaden epitopes and human clinical trials.

\section{Biology and life cycle of leishmania parasites}

Leishmania parasites are transmitted to the vertebrate host by sand flies that inject the parasite infective metacyclic promastigote forms under the skin [9]. Promastigotes are engulfed by phagocytic cells either resident or recruited to the wound site. Productive infections are established in macrophages, where promastigotes differentiate to amastigotes and replicate inside the parasitophorous vacuole $\left[10^{\bullet}, 11\right]$. Importantly, except for the first hours of 
infection, the amastigote is the only parasite stage persisting in the vertebrate host, and thus, need to be kept in check by the host immune response, in order to prevent disease. After macrophage rupture, free amastigotes reach the interstitial fluid or blood flow and are ingested by the female sand fly, during its blood meal. In the sand fly, amastigotes undergo a developmental differentiation to infective and flagellated metacyclic promastigotes. This final form reaches the fly saliva, which is introduced into the host skin at the next blood meal, closing the parasite cycle in nature $[9,11]$.

\section{Immunological correlates with the clinical outcome of visceral leishmaniasis}

T cell-mediated (type 1) immune responses are necessary to control Leishmania multiplication and dissemination, both in humans and dogs $\left[1^{\bullet}, 12^{\bullet}\right]$. Individuals with VL display an impaired ability to produce IFN- $\gamma$, allowing parasite multiplication and progressive disease $\left[1^{\circ}\right]$. While IL-12, IFN- $\gamma$ and TNF- $\alpha$, are regarded as crucial for parasite control and resolution of disease, a growing body of evidences indicate an important role of IL-10 and TGF- $\beta$ in down modulating type 1 responses, resulting in parasite persistence in the host and development of severe forms of both human and canine VL [12-17].

When injected into the skin, L. donovani promastigotes first interact with resident cells, including dermal macrophages and dendritic cells (DCs) $\left[10^{\circ}\right]$. The DCs will then secrete cytokines such as IL-12 or type I IFN that promote the polarization of naive $\mathrm{T}$ cells into Th1 effector lymphocytes [18,19]. Natural killer (NK) cells also participate in the innate immune response and control of the parasites, as an early source of IFN- $\gamma$ and contribute to the development of Th1 cells that produce high levels of IFN- $\gamma$ and TNF- $\alpha$ [20]. Whereas IFN- $\gamma$ and TNF- $\alpha$ activate macrophages to generate toxic molecules, radical nitrogen intermediates (RNI) or radical oxygen intermediates (ROI) that destroy Leishmania parasites inside macrophages [21]. On the contrary, IL-10 and TGF- $\beta$ suppress IL-12 production by macrophages and DCs, modulate the development of an adequate Th1 response $[15,22,23]$, preventing resolution of infection.

$\mathrm{CD}^{+}$Cytolytic $\mathrm{T}$ lymphocytes (CTL) are also clearly essential for the control of primary infections in mouse model of VL. Depletion of this cell subset abrogates the capacity of the host to eliminate amastigotes from the phagocytic cells [24]. Furthermore, CD8+ cells are the predominant population in liver granuloma in the late stages of the infection during resolution of infection [25]. Besides effective clearance of parasites [26], CD8+ cells also correlate with protection following vaccination and cure upon immunotherapy [27-29,30*0. In dogs, increased levels of CD8+ lymphocytes appear to be the major phenotypic feature of asymptomatic disease [31].
These cells have also been associated with cure in VL patients [26].

On the contrary, high titers of parasite-specific IgG positively correlate with symptomatic VL $(12,13,17)$. Indeed, mice lacking B lymphocytes or the Fcy receptor expressed by macrophages are resistant to infections with Leishmania $[32,33]$. It has been proposed that opsonization will favor parasite uptake, and therefore replication within macrophages. Furthermore, the importance of antibody-opsonized parasites in promoting VL may also be related to the induction IL-10 by macrophages [34]. B cells have also shown to produce IL-10 during VL [35]. Thus, the role of B-cells and IL-10 interfering with parasite/macrophage interaction and augmenting VL severity is an important issue and require further investigation.

\section{Protective immunity and the development of vaccines for visceral leishmaniasis}

Based on the immunological correlates of disease severity, as well as experimental infections of mice, an ideal protective immune response induced by vaccination against VL should aim to: (i) induce the production of IL-12 by professional antigen presenting cells (APCs) (i.e. DCs and macrophages); (ii) minimize the production of IL-10 by either T lymphocytes and APCs; (iii) induce a strong and long lasting response mediated by parasitespecific $\mathrm{CD}^{+}{ }^{+} \mathrm{Th} 1$ lymphocytes that produce high levels of IL-2, IFN- $\gamma$ and TNF- $\alpha$; (iv) induce a strong and long lasting response mediated by parasite-specific CD $8^{+}$CTLs that produce high levels of IFN- $\gamma$ and TNF- $\alpha$; and (v) avoid the induction of high levels of parasite-specific antibodies that may favor development of disease. To achieve these aims one should carefully select the antigen that has both $\mathrm{CD}^{+} \mathrm{T}$ and $\mathrm{CD}^{+} \mathrm{T}$ cell epitopes, the immunological adjuvant or live attenuated vector, the site of immunization as well as the dose and schedule of immunization.

During the past decades, many Leishmania antigens have been identified and tested for vaccine development. A comprehensive compilation of candidate antigens, vaccine formulations and trials may be found in other publications $\left[36-41,42^{\bullet \bullet}\right]$. However, even with the most appropriate antigen, another critical issue is how antigens are presented to the immune system. It is generally agreed that adjuvants used in leishmaniasis vaccine formulations should induce type 1 immune responses such as IL-12, saponin, BCG, Monophosphoril Lipid A (MPL) [43,44], CpG and recombinant virus [45-48]. Induction of IL-12 is critical for vaccine efficiency [49] and many of these adjuvants activate the innate immune response via the Toll-like receptors (TLR), modeling the acquired immune responses [50,51]. Heterologous prime-boost immunization protocols involving recombinant virus, DNA or recombinant protein, have been also tested with 
various antigens to increase vaccine potency [52-55]. Recently, however, long lasting protective immunity has been associated to induction of antigen specific poly-functional T-cells, which express simultaneously IFN$\gamma$, TNF- $\alpha$ and IL-2 [47]. However, little is known about an immunization protocol that induces long-term memory $\mathrm{T}$ lymphocytes that mediate protective immunity.

\section{The rational for an amastigote-specific visceral leishmaniasis vaccine}

Amastigote antigens have been far least tested as vaccine candidates against VL. The easiness that promastigotes can be cultured in vitro, as opposed to the fact that, for many years, axenic amastigotes could not be cultivated and were obtained only from host tissues, has hampered the identification of stage specific antigens [56]. Thus, most studies on Leishmania vaccines have focused on promastigote antigens. However, the amastigotes seem to be the more appropriate target for the immune responses elicited by a vaccine, since after few hours of initial infection and during the active disease, only this parasite stage is present in the host tissues. In addition, in oppose to promastigotes, the amastigotes reside inside host cells, and are targets for $\mathrm{CD}^{+}$CTLs, important elements for protective immunity against different species of Leishmania sp.

A main argument for an anti-promastigote vaccine is that sterile protection could be achieved by induction of an efficient immune response that eliminates the promastigotes soon after parasite transmission by the sand fly. However, protective immunity induced by promastigote antigens through vaccination is disrupted when challenge is performed through natural sand fly bite [57]. It is proposed that components of sand fly's saliva trigger the release of immunomodulators, for example, IL-10, at the site of parasite transmission, preventing the effective action of parasite specific $\mathrm{T}$ cell mediated immunity [11]. Since, these pharmacological active substances from the sand fly act locally and stay only for short periods in the host [58]; they are not likely to affected systemic anti-amastigote immune responses that will act at the later stages of infection. Importantly, when infection with Leishmania parasites is subclinical (asymptomatic) and the host become immunocompromised, as in HIV patients, the infection develops in severe disease [3]. In addition, solid protective immunity is achieved by vaccination with live attenuated Leishmania, but not with heat killed organisms or parasite lysates [59-61]. Together, these findings indicate the necessity of amastigote persistence in the host for maintenance of protective immunity. Thus, we conclude that a vaccine that elicits immune responses against intracellular amastigotes will have various advantages for both prophylactic and therapeutic vaccines: (i) it will act soon after promastigotes invade macrophages and transform in amastigotes, as well as later at stages of infection; (ii) it will allow the development of an CTL immune response that target intracellular parasites; (iii) it remains efficacious at later stages of infection, despite the initial immunomodulatory effects of sand fly saliva; and (iv) act on parasites that evade initial immune responses and manage to gain the inner compartments of host cells.

\section{Amastigote antigen 2 (A2), the selected antigen for VL vaccine}

Among the few amastigote antigens tested so far as vaccine against $\mathrm{VL}$, the $\mathrm{A} 2$ antigen has emerged as the most promising candidate. Table 1 summarizes the evidence for biological aspects, immunogenicity and protective responses induced by vaccination with $\mathrm{A} 2$, which is encoded by a multigene family that are abundantly expressed by amastigotes of leishmania species that cause VL [62-64]. The multigene family encode a set of

\section{Table 1}

\begin{tabular}{|c|c|c|}
\hline Properties & Biological evidence & Reference \\
\hline $\begin{array}{l}\text { A2 antigen identification and characterization } \\
\text { of biological role }\end{array}$ & $\begin{array}{l}\text { Amastigote specific, species distribution, } \\
\text { virulence factor, visceralization of parasite, stress protein }\end{array}$ & {$\left[62-64,65^{\bullet \bullet}, 66-68\right]$} \\
\hline Immunogenicity & $\begin{array}{l}\text { In silico epitope prediction; Recognized by antibodies and } \\
\text { lymphocytes of mice, dogs and patients with VL }\end{array}$ & {$\left[30^{\bullet \bullet}, 64,70,72\right]$} \\
\hline $\begin{array}{l}\text { Protective responses in pre-clinical tests of } \\
\text { vaccine formulations }\end{array}$ & $\begin{array}{l}\text { Significant reduction of symptoms and parasite burdens } \\
\text { upon vaccination either with recombinant protein, plasmid } \\
\text { DNA, transfected non-pathogenic } L \text {. tarentolae or } \\
\text { Lactococcus lactis or adenovirus expressing A2 }\end{array}$ & {$\left[30^{\bullet}, 73-78\right]$} \\
\hline $\begin{array}{l}\text { Protective immune responses against VL in } \\
\text { Rhesus monkeys }\end{array}$ & $\begin{array}{l}\text { Prime boost vaccination protocols consisting adenovirus } \\
\text { expressing A2 and the recombinant protein A2 resulted in } \\
\text { complete resolution of hepatic granuloma and elimination } \\
\text { of parasites in liver }\end{array}$ & Unpublished results \\
\hline Protective responses in dogs & Induction of type I protective immune responses in phase II & {$\left[79^{\circ}\right]$} \\
\hline $\begin{array}{l}\text { Protective responses in dogs induced by a } \\
\text { recombinant protein commercial brand } \\
\left(\text { Leish-Tec }{ }^{\mathbb{R}}\right)\end{array}$ & $\begin{array}{l}\text { trial in beagle dogs of a recombinant protein formulation } \\
\text { A randomized placebo controlled phase III trial in an endemic } \\
\text { area for } V L \text { resulted in } 71 \% \text { of protection against infection } \\
\text { based on parasitological tests and } 83 \% \text { among } A 2 \text { responsive animals }\end{array}$ & Unpublished results \\
\hline
\end{tabular}




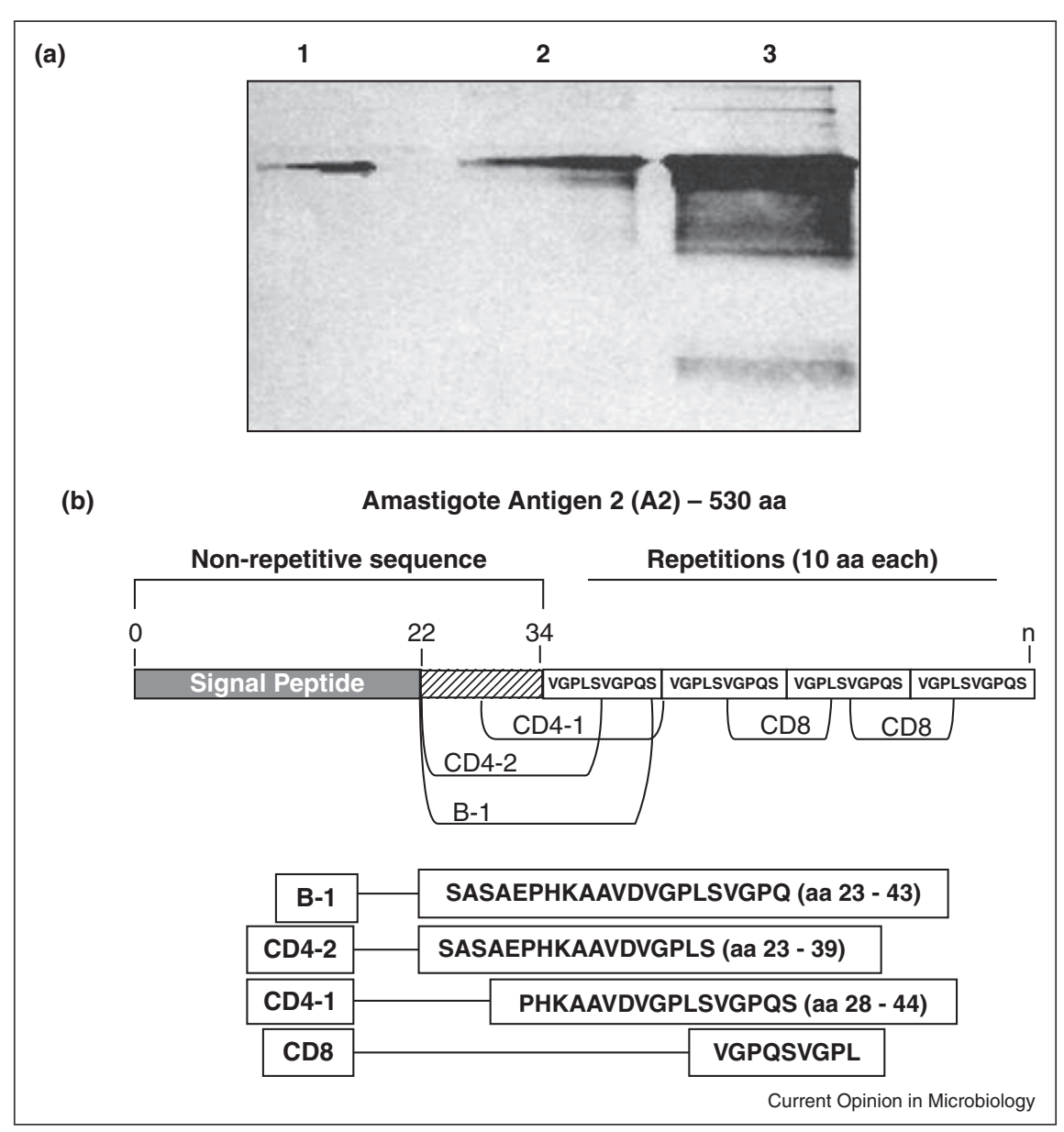

(A) Immunoblot analysis of amastigote extracts showing that besides $L$. donovani, L. amazonensis and L. chagasi amastigotes also express A2 proteins, as previously published [70]. Total protein lysates of $L$. amazonensis (lane 2) and $L$. chagasi (lane 3 ) amastigotes cultured at $37{ }^{\circ} \mathrm{C}$ and acid pH were submitted to $12 \%$ SDS-PAGE and transferred to nitrocellulose membranes. The C9 monoclonal antibody was used to detect the presence of A2 proteins. (License to use this figure - Elsevier license number: 2854920715893.)

(B) Epitope (CD4, CD8 and B cells) virtual mapping of A2, as previously described [30]. (License to use this figure - Elsevier license number: 2854910274786.)

proteins ranging from 45 to $110 \mathrm{kDa}$, primarily composed of repetitive units of 10 aminoacids. A2 proteins are closely associated with the parasite nuclei during infection with L. donovani and partly colocalize with HSP83, a cytosol protein. Moreover, they colocalize very similarly with $\mathrm{BiP}$, a endoplasmic reticulum chaperone protein, suggesting an endoplasmic reticulum localization for A2 $\left[65^{\circ}\right]$. Furthermore, the A2 is an important virulence factor [66], which is critical in the visceralization process of L. donovani [67-69].

In silico analyses revealed two $\mathrm{CD}^{+} \mathrm{T}$ cell epitopes (SASAEPHKAAVDVGPLS/PHKAAVDVGPLSVGPQS) in the $\mathrm{N}$ terminal portion of 34 aminoacids that correspond to the non-repetitive segment of A2 [30]. It was also determined that the repetitive unit composed by the
VGPQSVGPL motif has high affinity for different MHC I class haplotypes, and TAP, being a potential epitope for $\mathrm{CD}^{+}$CTLs (Figure 1B). The main B cell epitope of A2 was mapped and shown to be the secondary structure of a peptide containing two repetitive units of A2 (Figure 2A). The two CD4 ${ }^{+} \mathrm{T}$ cell epitopes induced production of IFN- $\gamma$ in recall response of splenocytes from infected or A2 vaccinated BALB/c mice (Figure 2B). The $\mathrm{CD}^{+} \mathrm{T}$ cell epitopes (repetitive unit) induced, besides production of INF- $\gamma$ (Figure 2B), cytotoxic activity in vivo in mice that were vaccinated with adenovirus expressing A2 [30]. Importantly, the levels of antiA2 antibodies are higher in asymptomatic animals as compared with the symptomatic ones [70,71], thus indicating a potential role in protective immunity elicited in infection with L. infantum. The A2 antigen also contains B 
Figure 2

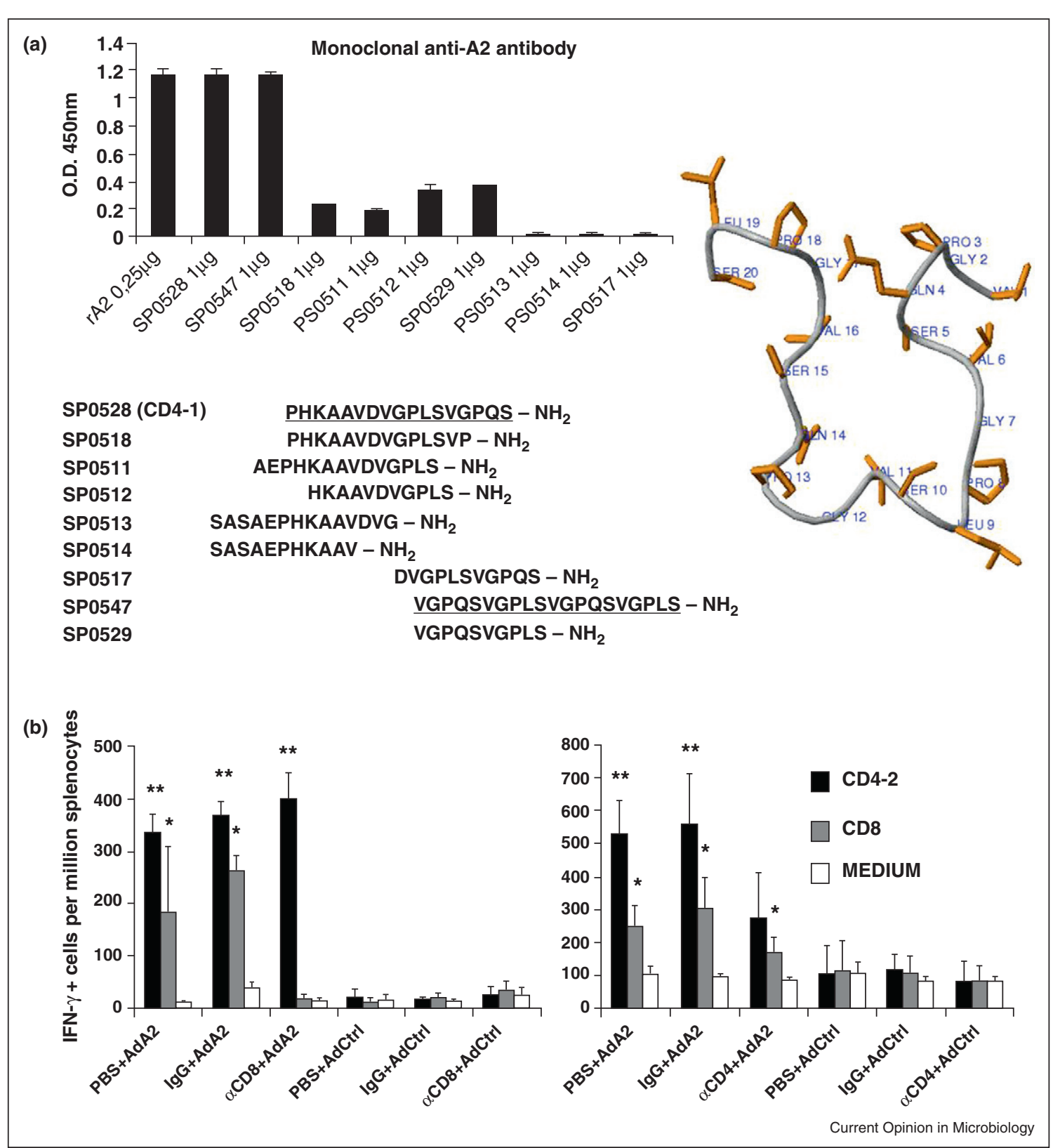

(A) B cell epitope mapping of A2. Shorter peptide sequences based on reactive peptides CD4-1 and B-1 (Figure 1B) and peptides composed of A2 repetitions were tested in ELISA against anti-A2 monoclonal antibody in order to determine the minimal B epitope, as previously described [30]. (License to use this figure - Elsevier license number: 2854910274786.)

(B) T cell epitope mapping of A2, as previously described [30]. ELISPOT assay performed with spleen cells of BALB/c mice submitted to depletion of CD8+ or CD4+ T cells followed by immunization with one dose of adenovirus. Spleen cells were stimulated with the peptides CD4-2 and CD8, described in Figure 1B. (License to use this figure - Elsevier license number: 2854910274786.)

and $\mathrm{T}$ cell epitopes recognized by human cells, which is an important requirement for induction of protection against leishmaniasis $[64,70,72]$.

During infection, since A2 contains both CD4 and CD8 epitopes, infected cells present these epitopes on the context of MHC II and MHC I molecules, resulting in activation of $\mathrm{CD}^{+} \mathrm{T}$ as well as $\mathrm{CD}^{+} \mathrm{T}$ lymphocytes, respectively. In the case of an $\mathrm{A} 2$ vaccinated host, the CD4 and CD8 A2 epitopes that were presented to immune system during vaccination will induce high production of IFN-gamma from both $\mathrm{CD}^{+}{ }^{+} \mathrm{T}$ and $\mathrm{CD} 8^{+} \mathrm{T}$ lymphocytes, resulting in activation of macrophages that will kill infective parasites. In addition, the A2 CD8 
epitope induces in vivo CD8 cytotoxic cells that will recognize and also kill infected macrophages.

Together, the fact that A2 is (i) conserved among the different species that cause VL, (ii) expressed in high levels by intracellular amastigotes, (iii) encode potent immunogenic CD4+ T cell epitopes, and (iv) in particular expresses at least $30 \mathrm{CD} 8+\mathrm{T}$ cell epitopes, makes it a very attractive vaccine candidate for VL. The next major challenge is to define a vaccine formulation, and an immunization protocol that elicits an appropriate immune response that leads to protection against VL.

\section{Formulations of A2 vaccine: aiming induction of a prominent T-cell mediated immunity}

Several pre-clinical tests, which included administration of A2 antigens either as recombinant protein associated to different adjuvants [73,74], DNA [75,76], attenuated nonreplicative viruses [30], non-pathogenic bacteria [77] or non-virulent parasites (L. tarentolae) [78], have provided evidence of the protective effect of vaccination in mice. In general, A2 vaccine induced protective immunity was associated to parasite specific $\operatorname{IgG2a}$ antibodies, as well as high levels of IFN- $\gamma$ and low levels of IL-10 produced by $\mathrm{T}$ cells in recall response to parasite antigens. Protective immunity results in reduced lesion size and numbers of parasites in protected animals [73-78]. Given the impressive reductions in parasite burdens at the site of infection and in distant body sites, anti-A2 immune responses may act by promoting clearance of parasites instead of only preventing their dissemination.

A recombinant protein formulation consisting of saponin, as adjuvant and the recombinant protein $\mathrm{A} 2$ has also been tested in a phase II trial in dogs $\left[79^{\circ}\right]$. Vaccinated dogs presented high levels of anti-A2 IgG and IgG2, but not IgG1 antibodies, and high IFN- $\gamma$ and low IL-10 levels in response to both $\mathrm{A} 2$ and total antigenic extracts of parasites. After challenge, 5 out of 7 control animals presented severe symptoms of VL as early as three months, such as bloody diarrhea and intense weight losses. By contrast, 5 out of 7 vaccinated animals remained asymptomatic throughout the tests. The 2 symptomatic animals presented low grade of symptoms, which appeared only one year after the
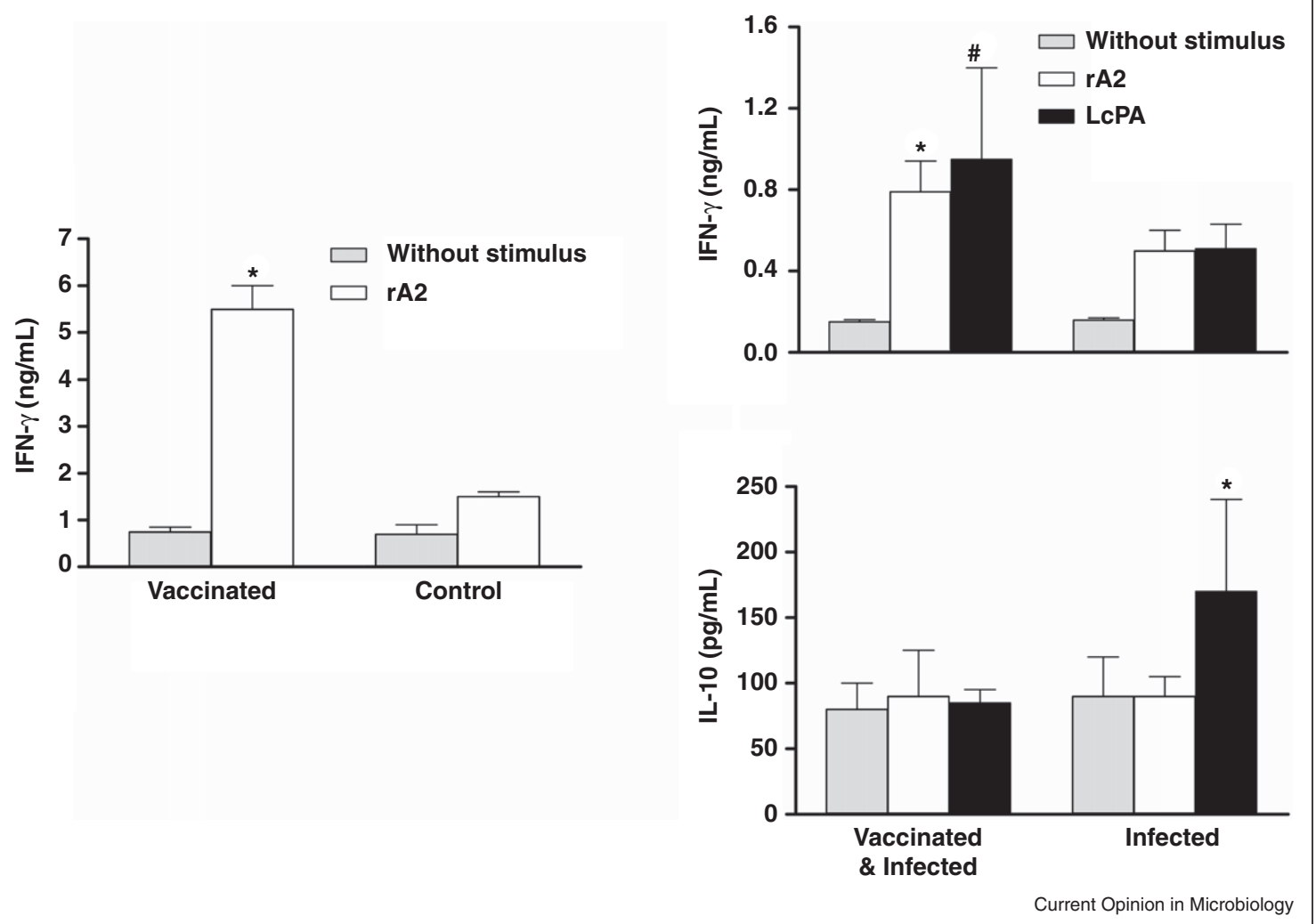

Immune responses induced by a vaccine formulation containing the recombinant protein A2 and saponin in dogs (phase II trial), as previously described [79"]. Cytokine levels detected in culture supernatants of canine PBMC. The left panel shows IFN- $\gamma$ levels detected after immunization and before infection in PBMC culture supernatants stimulated with rA2. The right upper panel shows levels of IFN- $\gamma$ detected in PBMC culture supernatants produced in response to rA2 or LcPA, seven months after infection. The right lower panel shows levels of IL-10 in response to rA2 or LcPA seven months after infection. The asterisks and \# indicate that differences are statistically significant $(p<0.05)$. (License to use these figures - Elsevier license number: 2854901184204.) 
infection (Figure 3). Importantly, after vaccination, the dogs remained negative in serological tests using promastigote antigens, indicating that vaccination with $\mathrm{A} 2$ allows the serology distinction between immunized and infected dogs.

Based on this, a protein formulation (Leish-Tec ${ }^{\circledR}$ ) was licensed in Brazil, the third prophylactic vaccine against canine VL, but the first recombinant one commercialized in world. Leish-Tec ${ }^{\mathbb{R}}$ was also immunogenic and safe for a heterogeneous dog population. Increased anti-A2 total $\operatorname{IgG}, \operatorname{IgG} 2$ and IgG1 antibody titers were detected one month after vaccination, in a high percentage of the animals, increasing again after the boosting [manuscript in preparation].

A double-blinded randomized phase III trial was also performed to test the efficacy of Leish-Tec ${ }^{\circledR}$ in an endemic area of VL, located in the city of Porteirinha, Minas Gerais, Brazil. In this study, 1650 healthy dogs were included, following statistical analysis. Dogs were accompanied for follow up period of one year, when $96 \%$ of the Leish-Tec ${ }^{\mathbb{R}}$ vaccinated dogs remained not infected leading to a significant protective efficacy $(71 \%)$, based on the recovery of parasites through culture of bone marrow aspirates. Among the animals that presented anti-A2 antibodies in response to Leish-Tec ${ }^{\circledR}, 82 \%$ of protection has been achieved [manuscript in preparation].

Finally, a pre-clinical trial in Rhesus monkeys was also conducted, aiming to test, through homologous or heterologous prime-boost protocols, the protective responses induced by adenovirus, plasmids expressing $\mathrm{A} 2$ or the recombinant A2. In comparison to the control groups, the vaccinated monkeys displayed a significant capacity to control parasite replication. The vaccination with recombinant protein and adenovirus expressing A2 provided the best results, leading to complete granuloma resolution and elimination of parasites in hepatic biopsies, as confirmed by real time PCR analysis. These results are quite promising from the perspective of developing vaccines against human VL, since Rhesus monkeys are one of the closest infection models to human VL [Grimaldi et al., manuscript in preparation].

\section{Efforts to further improve A2 based vaccines}

While a large amount of encouraging results have been obtained, employing different vaccine formulations containing the A2, the heterogeneity of MHC molecules is still a major barrier to make a vaccine that protects a vast majority of the target canine and human populations. Thus, it is essential to identify other $L$. (L.) infantum antigens that could be aggregated to the $\mathrm{A} 2$ based vaccine. By employing immunoproteomics our group has identified new promising multi-epitope Leishmaniaantigens.

Differential expression of proteins between tissue amastigotes and promastigotes forms of $L$. infantum was analyzed by immunoproteomics [80]. Several proteins were identified by mass spectrometry (MS), including 25 expressed in promastigotes, 5 expressed in amastigotes and 10 proteins expressed in both Leishmania stages. Many of these proteins were hypothetical, as previously detected by genomic approaches. In a second study, we compared the reactivity of sera of asymptomatic and symptomatic dogs with proteins expressed by axenic promastigotes and amastigotes $\left[81^{\circ}\right]$. Among the proteins identified in promastigotes and amastigotes extracts, we found various known and hypothetical proteins that are recognized by either sera of symptomatic or asymptomatic dogs. All these proteins identified by immunoproteomics were screened in silico for potential T cell epitopes. We also tested the ability of each peptide/protein to bind to 10 different HLA supertypes, MHC I potential B cell epitope prediction. Altogether, the data obtained disclosed many new antigens that are potential vaccine candidates, which are currently been tested in experimental murine model of VL.

\section{Perspectives}

Altogether, the results discussed above constitute a solid base for the development of a vaccine for human VL. Our proposal is to initiate a phase I clinical trial to evaluate safety, immunogenicity of the selected vaccine formulation containing A2. The adenovirus expressing A2 and recombinant $\mathrm{A} 2$ associated to adjuvants that are licensed to be used in humans are the natural candidates for the vaccine formulation. However, a continuous search for new adjuvants, live attenuated vaccine vectors, as well as additional immunogenic parasite proteins may further improve efficacy of A2 vaccine.

\section{Acknowledgements}

Authors apologize for not citing many important references that have contributed to this review owing to space limitations. Authors thank all students that have contributed with the work discussed herein. This work was funded partly by grants from the National Institute for Science and Technology of Vaccines $(\mathrm{CNPq})$ and The Network Research in Biomolecules (FAPEMIG). RTG, APF and EAFC received research fellowships from CNPq.

\section{References and recommended reading}

Papers of particular interest, published within the period of review, have been highlighted as:

- of special interest

$\bullet$ of outstanding interest

1. Schriefer A, Wilson ME, Carvalho EM: Recent developments - leading toward a paradigm switch in the diagnostic and therapeutic approach to human leishmaniasis. Curr Opin Infect Dis 2008, 21:483-488.

Characterizes leishmaniasis as group of syndromes, and provides a synthetic description of the distinct immunopathological mechanisms leading to the main syndromes.

2. Grimaldi G Jr, Tesh RB, McMahon-Pratt D: A review of the geographic distribution and epidemiology of leishmaniasis in the New World. Am J Trop Med Hyg 1989, 41:687-725.

3. Berman J: Visceral leishmaniasis in the New World \& Africa. Indian J Med Res 2006, 123:289-294.

4. Cupolillo E, Aguiar Alves F, Brahim LR, Naiff MF, Pereira LO, Oliveira-Neto MP, Falqueto A, Grimaldi G Jr: Recent advances in 
the taxonomy of the New World leishmanial parasites. Med Microbiol Immunol 2001, 190:57-60.

5. Mauricio IL, Stothard JR, Miles MA: Leishmania donovani complex: genotyping with the ribosomal internal transcribed spacer and the mini-exon. Parasitology 2004, 128:263-267.

6. Hotez PJ, Remme JH, Buss P, Alleyne G, Morel C, Breman JG: Combating tropical infectious diseases: report of the disease control priorities in developing countries project. Clin Infect Dis 2004, 38:871-878.

7. Desjeux P: Leishmaniasis: current situation and new perspectives. Comp Immunol Microbiol Infect Dis 2004, 27:305-318.

8. Croft S, Olliaro P: Leishmaniasis chemotherapy: challenges and opportunities. Clin Microbiol Infect 2011, 17:1478-1483.

9. Sacks DL: Metacyclogenesis in Leishmania promastigotes. Exp Parasitol 1989, 69:100-103.

10. Kaye P, Scott P: Leishmaniasis: complexity at the hostpathogen interface. Nat Rev Microbiol 2011, 9:604-615.

Discuss the diversity of host-pathogen interactions in leishmaniasis, the distinct solutions to the problems of parasite establishment, survival and persistence and the implications for vaccines development, drugs and immunotherapeutic interventions.

11. Peters NC, Sacks DL: The impact of vector-mediated neutrophil recruitment on cutaneous leishmaniasis. Cell Microbiol 2009, 11:1290-1296.

12. Reis $A B$, Giunchetti RC, Carrillo E, Martins-Filho OA, Moreno J:

- Immunity to Leishmania and the rational search for vaccines against canine leishmaniasis. Trends Parasitol 2010, 26:341-349.

Reviews major aspects associated to immune responses, biomarkers of infection and protective responses and their implication for development of canine visceral leishmaniasis vaccines.

13. Ganguly S, Das NK, Panja M, Pal S, Modak D, Rahaman M, Mallik S, Guha SK, Pramanik N, Goswami R et al.: Increased levels of interleukin-10 and IgG3 are hallmarks of Indian postkala-azar dermal leishmaniasis. J Infect Dis 2008, 197:1762-1771.

14. Saha S, Mondal S, Ravindran R, Bhowmick S, Modak D, Mallick S Rahman M, Kar S, Goswami R, Guha SK et al.: IL-10- and TGFbeta-mediated susceptibility in kala-azar and post-kala-azar dermal leishmaniasis: the significance of amphotericin B in the control of Leishmania donovani infection in India. $J$ Immunol 2007, 179:5592-5603.

15. Nylen S, Sacks D: Interleukin-10 and the pathogenesis of human visceral leishmaniasis. Trends Immunol 2007, 28:378-384.

16. Alves CF, de Amorim IF, Moura EP, Ribeiro RR, Michalick MS Kalapothakis E, Bruna-Romero O, Tafuri WL, Teixeira MM, Melo MN: Expression of IFN-gamma, TNF-alpha, IL-10 and TGF-beta in lymph nodes associates with parasite load and clinical form of disease in dogs naturally infected with Leishmania (Leishmania) chagasi. Vet Immunol Immunopathol 2009, 128:349-358.

17. Barbieri CL: Immunology of canine leishmaniasis. Parasite Immunol 2006, 28:329-337.

18. Ghosh M, Mandal L, Maitra S, Rakshit S, Paul K, Bagchi J, Ganguly D, Pal C, Bandyopadhyay S: Leishmania donovani infection of human myeloid dendritic cells leads to a Th1 response in CD4+ T cells from healthy donors and patients with kala-azar. J Infect Dis 2006, 194:294-301.

19. Pepe M, Altamura M, Spinelli R, Calvello R, Saccia M, Cavallo P Covelli V, Jirillo $E$, Brandonisio $O$ : Toll-like receptor-positive cells and recognition of pathogens: how human myeloid dendritic cells respond to in vitro infection with Leishmania infantum. Curr Pharm Des 2006, 12:4255-4262.

20. Prajeeth CK, Haeberlein S, Sebald H, Schleicher U, Bogdan C: Leishmania-infected macrophages are targets of NK cellderived cytokines but not of NK cell cytotoxicity. Infect Immun 2011, 79:2699-2708.
21. Murray HW, Nathan CF: Macrophage microbicidal mechanisms in vivo: reactive nitrogen versus oxygen intermediates in the killing of intracellular visceral Leishmania donovani. J Exp Med 1999, 189:741-746.

22. Nylén S, Maurya R, Eidsmo L, Manandhar KD, Sundar S, Sacks D: Splenic accumulation of IL-10 mRNA in T cells distinct from CD4+CD25+ (Foxp3) regulatory T cells in human visceral leishmaniasis. J Exp Med 2007, 204:805-817.

23. Haeberlein S, Sebald H, Bogdan C, Schleicher U: IL-18, but not IL-15, contributes to the IL-12-dependent induction of NK-cell effector functions by Leishmania infantum in vivo. Eur $J$ Immunol 2010, 40:1708-1717.

24. Stern JJ, Oca MJ, Rubin BY, Anderson S, Murray H: Role of L3T4+ and Lyt-2+ cells in experimental visceral leishmaniasis. $J$ Immunol 1988, 141:3971-3977.

25. Mc Elrath MJ, Murray HW, Cohn ZA: The dynamics of granuloma formation in experimental visceral leishmaniasis. $J$ Exp Med 1988, 167:1927-1937.

26. Mary C, Auriault V, Faugere B, Dessein AJ: Control of Leishmania infantum infection is associated with CD8+ and IFN-gammaand interleukin-5-producing $\mathrm{CD4}^{+}$antigen-specific $\mathrm{T}$ cells. Infect Immun 1999, 67:5559-5566.

27. Stager S, Alexander J, Kirby AC, Botto M, Rooijen NV, Smith DF Brombacher F, Kaye PM: Natural antibodies and complement are endogenous adjuvants for vaccine-induced CD8+ T-cell responses. Nat Med 2003, 9:1287-1292.

28. Basu R, Bhaumik S, Haldar AK, Naskar K, De T, Dana SK Walden $\mathrm{P}$, Roy S: Hybrid cell vaccination resolves Leishmania donovani infection by eliciting a strong CD8+ cytotoxic $\mathrm{T}$ lymphocyte response with concomitant suppression of interleukin-10 (IL-10), but not IL-4 or IL-13. Infect Immun 2007, 75:5956-5966.

29. Polley R, Stager S, Prickett S, Maroof A, Zubairi S, Smith DF, Kaye PM: Adoptive immunotherapy against experimental visceral leishmaniasis with CD8+ $T$ cells requires the presence of cognate antigen. Infect Immun 2006, 74:773-776.

30. Resende DM, Caetano BC, Dutra MS, Penido ML, Abrantes CF,

- Verly RM, Resende JM, Piló-Veloso D, Rezende SA, BrunaRomero $\mathrm{O}$ et al.: Epitope mapping and protective immunity elicited by adenovirus expressing the Leishmania amastigote specific A2 antigen: correlation with IFN-gamma and cytolytic activity by CD8+ T cells. Vaccine 2008, 26:4585-4593.

Reports on the construction of a recombinant adenovirus expressing the $\mathrm{A} 2$ antigen and the $\mathrm{B}, \mathrm{CD} 4$ and CD8 cell epitope mapping of this amastigote $\mathrm{A} 2$.

31. Reis AB, Martins-Filho OA, Teixeira-Carvalho A, Giunchetti RC, Carneiro CM, Mayrink W, Tafuri WL, Corrêa-Oliveira R: Systemic and compartmentalized immune response in canine visceral leishmaniasis. Vet Immunol Immunopathol 2009, 128:87-95.

32. Smelt SC, Cotterell SE, Engwerda CR, Kaye PM: B cell-deficient mice are highly resistant to Leishmania donovani infection, but develop neutrophil-mediated tissue pathology. J Immunol $2000,164: 3681-3688$

33. Thomas BN, Buxbaum LU: Fc gamma-RIII mediates immunoglobulin $\mathrm{G}$-induced interleukin-10 and is required for chronic Leishmania mexicana lesions. Infect Immun 2008, 76:623-631.

34. Miles SA, Conrad SM, Alves RG, Jeronimo SM, Mosser DM: A role for IgG immune complexes during infection with the intracellular pathogen Leishmania. J Exp Med 2005 201:747-754.

35. Maroof A, Beattie L, Zubairi S, Svensson M, Stager S, Kaye PM: Post-transcriptional regulation of IL-10 gene expression allows natural killer cells to express immunoregulatory function. Immunity 2008, 29:295-305.

36. Dumonteil E: DNA vaccines against protozoan parasites: advances and challenges. J Biomed Biotechnol 2007, 2007:90520.

37. Kedzierski L, Zhu Y, Handman E: Leishmania vaccines: progress and problems. Parasitology 2006, 133(Suppl.):S87-S112. 
38. Gradoni L: An update on antileishmanial vaccine candidates and prospects for a canine Leishmania vaccine. Vet Parasitol 2001, 100:87-103.

39. Kedzierski L, Sakthianandeswaren A, Curtis JM, Andrews PC, Junk PC, Kedzierska K: Leishmaniasis: current treatment and prospects for new drugs and vaccines. Curr Med Chem 2009, 16:599-614.

40. Noazin S, Modabber F, Khamesipour A, Smith PG, Moulton LH, Nasseri K, Sharifi I, Khalil EA, Bernal ID, Antunes CM et al.: First generation leishmaniasis vaccines: a review of field efficacy trials. Vaccine 2008, 26:6759-6767.

41. Palatnik-de-Sousa CB: Vaccines for leishmaniasis in the fore coming 25 years. Vaccine 2008, 26:1709-1724.

42. Costa CHN, Peters NC, Maruyama SR, Brito EC Jr, Santos IKFM:

-. Vaccines for the Leishmaniases: proposals for a research agenda. The Working Group on research priorities for development of leishmaniasis vaccines. PLOS Negl Trop Dis 2011, 5:e943.

Discuss the main advances and limitations and propose an agenda to accelerate development of leishmaniasis vaccines. Includes a comprehensive list of candidate antigens, pre-clinical and clinical trials of leishmaniasis vaccines.

43. Santos WR, de Lima VM, de Souza EP, Bernardo RR, Palatnik M, Palatnik-de-Sousa CB: Saponins, IL-12 and BCG adjuvant in the FML-vaccine formulation against murine visceral leishmaniasis. Vaccine 2002, 21:30-43.

44. Reed SG, Coler RN, Campos-Neto A: Development of a leishmaniasis vaccine: the importance of MPL. Expert Rev Vaccines 2003, 2:239-252.

45. McMahon-Pratt D, Rodriguez D, Rodriguez JR, Zhang Y, Manson K, Bergman C, Rivas L, Rodriguez JF, Lohman KL, Ruddle $\mathrm{NH}$ et al:: Recombinant vaccinia viruses expressing GP46/M-2 protect against Leishmania infection. Infect Immun 1993, 61:3351-3359.

46. Gabaglia CR, Pedersen B, Hitt M, Burdin N, Sercarz EE, Graham FL, Gauldie J, Braciak TA: A single intramuscular injection with an adenovirus-expressing IL-12 protects BALB/ c mice against Leishmania major infection, while treatment with an IL-4-expressing vector increases disease susceptibility in B10.D2 mice. J Immunol 1999, 162:753-760.

47. Darrah PA, Patel DT, de Luca PM, Lindsay RW, Davey DF, Flynn BJ, Hoff ST, Andersen P, Reed SG, Morris SL et al.: Multifunctional $\mathrm{TH} 1$ cells define a correlate of vaccine-mediated protection against Leishmania major. Nat Med 2007, 13:843-850.

48. Rhee EG, Mendez S, Shah JA, Wu CY, Kirman JR, Turon TN, Davey DF, Davis H, Klinman DM, Coler RN et al.: Vaccination with heat-killed Leishmania antigen or recombinant leishmanial protein and CpG oligodeoxynucleotides induces long-term memory CD4+ and CD8+ $\mathrm{T}$ cell responses and protection against Leishmania major infection. J Exp Med 2002, 195:1565-1573.

49. Stobie L, Gurunathan S, Prussin C, Sacks DL, Glaichenhaus N, Wu CY, Seder RA: The role of antigen and IL-12 in sustaining Th1 memory cells in vivo: IL-12 is required to maintain memory/effector Th1 cells sufficient to mediate protection to an infectious parasite challenge. Proc Natl Acad Sci USA 2000 97:8427-8432.

50. Iwasaki A, Medzhitov R: Toll-like receptor control of the adaptive immune responses. Nat Immunol 2004, 5:987-995.

51. Zhang WW, Matlashewski G: Immunization with a Toll-like receptor 7 and/or 8 agonist vaccine adjuvant increases protective immunity against Leishmania major in BALB/c mice. Infect Immun 2008, 76:3777-3783.

52. Dondji B, Perez-Jimenez E, Goldsmith-Pestana K, Esteban M, McMahon-Pratt D: Heterologous prime-boost vaccination with the LACK antigen protects against murine visceral leishmaniasis. Infect Immun 2005, 73:5286-5289.

53. Ramiro MJ, Zarate JJ, Hanke T, Rodriguez D, Rodriguez JR, Esteban M, Lucientes J, Castillo JA, Larraga V: Protection in dogs against visceral leishmaniasis caused by Leishmania infantum is achieved by immunization with a heterologous prime-boost regime using DNA and vaccinia recombinant vectors expressing LACK. Vaccine 2003, 21:2474-2484.

54. Ramos I, Alonso A, Marcen JM, Peris A, Castillo JA, Colmenares M, Larraga V: Heterologous prime-boost vaccination with a non-replicative vaccinia recombinant vector expressing LACK confers protection against canine visceral leishmaniasis with a predominant Th1-specific immune response. Vaccine 2008, 26:333-344.

55. Carson C, Antoniou M, Ruiz-Arguello MB, Alcami A, Christodoulou V, Messaritakis I, Quinnell RJ, Blackwell JM Courtenay O: A prime/boost DNA/modified vaccinia virus Ankara vaccine expressing recombinant Leishmania DNA encoding TRYP is safe and immunogenic in outbred dogs, the reservoir of zoonotic visceral leishmaniasis. Vaccine 2009, 27:1080-1086.

56. Wenzel UA, Bank E, Florian C, Förster S, Zimara N, Steinacker J Klinger M, Reiling N, Ritter U, Van Zandbergen G: Leishmania major parasite stage-dependent host cell invasion and immune evasion. FASEB J 2012, 26:29-39.

57. Peters NC, Kimblin N, Secundino N, Kamhawi S, Lawyer P, Sacks DL: Vector transmission of Leishmania abrogates vaccine-induced protective immunity. PLoS Pathog 2009 5:e1000484.

58. Rohoušová I, Hostomská J, Vlková M, Kobets T, Lipoldová M, Volf $P$ : The protective effect against Leishmania infection conferred by sand fly bites is limited to short-term exposure. Int J Parasitol 2011, 41:481-485.

59. Titus RG, Gueiros-Filho FJ, de Freitas LA, Beverley SM: Development of a safe live Leishmania vaccine line by gene replacement. Proc Natl Acad Sci USA 1995, 92:10267-10271.

60. Silvestre R, Cordeiro-da-Silva A, Ouaissi A: Live attenuated Leishmania vaccines: a potential strategic alternative. Arch Immunol Ther Exp (Warsz) 2008, 56:123-126.

61. Kumari S, Samant M, Khare P, Misra P, Dutta S, Kolli BK, Sharma S, Chang KP, Dube A: Photodynamic vaccination of hamsters with inducible suicidal mutants of Leishmania amazonensis elicits immunity against visceral leishmaniasis. Eur J Immunol 2009, 39:178-191.

62. Charest $\mathrm{H}$, Matlashewski G: Developmental gene expression in Leishmania donovani: differential cloning and analysis of an amastigote-stage-specific gene. Mol Cell Biol 1994, 14:2975-2984

63. Zhang WW, Charest H, Ghedin E, Matlashewski G: Identification and over-expression of the A2 amastigote-specific protein in Leishmania donovani. Mol Biochem Parasitol 1996, 78:79-90.

64. Ghedin E, Zhang WW, Charest H, Sundar S, Kenney RT, Matlashewski G: Antibody response against a Leishmania donovani amastigote-stage-specific protein in patients with visceral leishmaniasis. Clin Diagn Lab Immunol 1997, 4:530-535.

65. McCall LI, Matlashewski G: Localization and induction of the A2

-. virulence factor in Leishmania: evidence that A2 is a stress response protein. Mol Microbiol 2010, 77:518-530.

Reports on the biological properties of A2 proteins on physiology and visceralization of Leishmania parasites.

66. Zhang WW, Matlashewski G: Loss of virulence in Leishmania donovani deficient in an amastigote-specific protein, A2. Proc Natl Acad Sci USA 1997, 94:8807-8811.

67. Zhang WW, Matlashewski G: Characterization of the A2-A2rel gene cluster in Leishmania donovani: involvement of A2 in visceralization during infection. Mol Microbiol 2001 , 39:935-948.

68. Mizbani A, Taslimi Y, Zahedifard F, Taheri T, Rafati S: Effect of A2 gene on infectivity of the nonpathogenic parasite Leishmania tarentolae. Parasitol Res 2011, 109:793-799.

69. Zhang WW, Mendez S, Ghosh A, Myler P, Ivens A, Clos J, Sacks DL, Matlashewski G: Comparison of the A2 gene locus in Leishmania donovani and Leishmania major and its control over cutaneous infection. J Biol Chem 2003, 278:35508-35515. 
70. Carvalho FA, Charest H, Tavares CA, Matlashewski G, Valente EP, Rabello A, Gazzinelli RT, Fernandes AP: Diagnosis of American Visceral Leishmaniasis in humans and dogs using the recombinant Leishmania donovani A2 antigen. Diagn Microbiol Infect Dis 2002, 43:289-295.

71. Porrozzi R, da Costa MVS, Teva A, Falqueto A, Ferreira AL, dos Santos CD, Fernandes AP, Gazzinelli RT, Campos-Neto A, Grimaldi G Jr: Comparative evaluation of enzime-linked immunosorbent assays based on crude and recombinant leishmanial antigens for serodiagnosis of symptomatic and asymptomatic Leishmania infantum visceral infections in dogs. Clin Vaccine Immunol 2007, 14:544-548.

72. Martins DR, Jeronimo SM, Donelson JE, Wilson ME: Leishmania chagasi T-cell antigens identified through a double library screen. Infect Immun 2006, 74:6940-6948.

73. Ghosh A, Zhang WW, Matlashewski G: Immunization with A2 protein results in a mixed Th1/Th2 and a humoral response which protects mice against Leishmania donovani infection. Vaccine 2001, 20:59-66.

74. Coelho EA, Tavares CAP, Carvalho FAA, Chaves KF, Teixeira KN, Rodrigues RC, Charest H, Matlashewski G, Gazzinelli RT, Fernandes AP: Immune responses induced by the Leishmania (Leishmania) donovani A2 antigen, but not by the LACK antigen, are protective against experimental Leishmania (Leishmania) amazonensis infection. Infect Immun 2003. 71:3988-3994.

75. Ghosh A, Labrecque S, Matlashewski G: Protection against Leishmania donovani infection by DNA vaccination: increased DNA vaccination efficiency through inhibiting the cellular p53 response. Vaccine 2001, 19:3169-3178.

76. Zanin FHC, Coelho EAF, Tavares CAP, Marques-da-Silva E, Costa MM, Resende SA, Gazzinelli RT, Fernandes AP: Evaluation of immune responses and protection induced by $A 2$ and nucleoside hydrolase (NH) DNA vaccines against Leishmania chagasi and Leishmania amazonensis experimental infection. Microbes Infect 2007, 9:1070-1077.

77. Yam KK, Hugentobler F, Pouliot P, Stern AM, Lalande JD, Matlashewski G, Olivier M, Cousineau B: Generation and evaluation of A2-expressing Lactococcus lactis live vaccines against Leishmania donovani in BALB/c mice. J Med Microbiol 2011, 60:1248-1260.

78. Mizbani A, Taheri T, Zahedifard F, Taslimi Y, Azizi H, Azadmanesh K, Papadopoulou B, Rafati S: Recombinant Leishmania tarentolae expressing the A2 virulence gene as a novel candidate vaccine against visceral leishmaniasis. Vaccine 2009, 28:53-62.

79. Fernandes AP, Costa MM, Coelho EA, Michalick MS, de Freitas E,

- Melo MN, Tafuri W, Hermont V, Resende DM, Abrantes C et al.: Protective immunity against challenge with Leishmania (Leishmania) chagasi in beagle dogs vaccinated with recombinant A2 protein. Vaccine 2008, 26:5888-5895. Describes the results of phase II clinical trial in dogs of an A2 antigen/ saponin vaccine based formulation.

80. Costa MM, Andrade HM, Bartholomeu DC, Freitas LM, Pires SF, Chapeaurouge AD, Perales J, Ferreira AT, Giusta MS, Melo MN et al.: Analysis of Leishmania chagasi by 2-D difference gel eletrophoresis (2-D DIGE) and immunoproteomic: identification of novel candidate antigens for diagnostic tests and vaccine. J Proteome Res 2011, 10:2172-2184.

81. Coelho VTS, Oliveira JS, Valadares DG, Chávez-Fumagalli MA,

- Duarte MC, Lage PS, Soto M, Santoro MM, Tavares CAP, Fernandes AP et al.: Identification of proteins in promastigote and amastigote-like stages of Leishmania using an immunoproteomic approach. PLoS Negl Trop Dis 2011, 6:1430. Describes new amastigote antigens identified through proteomic analysis of axenic amastigotes. 